\title{
Study of the stability of cashew nuts obtained from conventional and organic cultivation
}

\section{Estudo da estabilidade de amêndoas de castanha de caju obtidas dos cultivos convencional e orgânico}

\author{
Denise Josino Soares ${ }^{1 *}$; Carlos Eliardo Barros Cavalcante ${ }^{2}$; Thiago Gomes \\ Cardoso $^{3}$; Evânia Altina Teixeira de Figueiredo ${ }^{4}$; Geraldo Arraes Maia ${ }^{4}$; \\ Paulo Henrique Machado de Sousa ${ }^{5}$; Raimundo Wilane de Figueiredo ${ }^{4}$
}

\begin{abstract}
From the cashew tree, the cashew fruit is obtained which is composed of the nut and the cashew apple. In the last decade, there has been a substitution of the conventional system of food production for the organic cultivation system. Given the above, this research aimed to study the stability of cashew nuts obtained from conventional and organic cultivation. There were differences in the content of total soluble sugars and soluble solids between the two methods of cultivation studied, where the highest values were observed in nuts from conventional cultivation. As for the content of phenolic compounds and antioxidant activity by $\mathrm{ABTS}^{++}$and $\mathrm{DPPH}^{\cdot}$ radicals, the mean values observed were $65 \mathrm{mg} \mathrm{GAE} / 100 \mathrm{~g}$, $6.6 \mu \mathrm{M}$ Trolox/g and $30682 \mathrm{~g}$ of nut/g DPPH'. There was no reduction of the antioxidant activity of the cashew nuts during the storage in flexible packaging covered with laminated film, at room temperature $\left(25^{\circ} \mathrm{C}\right)$ during 180 days.
\end{abstract}

Key words: Bioactive compounds, storage, antioxidants, fruit quality

\section{Resumo}

Do cajueiro obtém-se o caju, que é composto pela castanha e pedúnculo. Nas últimas décadas, vem ocorrendo a substituição do sistema convencional de produção de alimentos pelo sistema de cultivo orgânico. Diante do exposto, essa pesquisa objetivou estudar a estabilidade de amêndoas de castanha de caju obtidas dos cultivos convencional e orgânico. Houve diferença no conteúdo de açúcares solúveis totais e sólidos solúveis entre as duas formas de cultivos estudadas, sendo os maiores valores observados nas amêndoas de cultivo convencional. Quanto ao conteúdo de compostos fenólicos e atividade antioxidante pelo radical $\mathrm{ABTS}^{\circ+}$ e pelo radical $\mathrm{DPPH}^{\circ}$, os valores médios observados foram de $65 \mathrm{mg}$ GAE/100 g de amêndoa, 6,6 $\mu \mathrm{M}$ Trolox/g de amêndoa e $30682 \mathrm{~g}$ de amêndoa/g de DPPH'. Não houve redução da atividade antioxidante das amêndoas de castanha de caju durante o armazenamento em embalagem flexível recoberta com filme laminado, a temperatura ambiente $\left(25^{\circ} \mathrm{C}\right)$ durante 180 dias.

Palavras-chave: Compostos bioativos, armazenamento, antioxidantes, qualidade de frutas

\footnotetext{
${ }^{1}$ Discente do Curso de Doutorado em Ciência e Tecnologia de Alimentos, Universidade Federal do Ceará, UFC, Fortaleza, CE. E-mail: denisejosino@hotmail.com

${ }^{2}$ Prof. Msc. do Instituto Federal de Educação, Ciências e Tecnologia do Ceará, Ubajara, CE. E-mail: c_eliardo@yahoo.com.br

${ }^{3}$ Discente do Curso de Engenharia de Alimentos, Universidade Federal do Ceará, UFC, Fortaleza, CE. E-mail: thiagogcardoso@ gmail.com

${ }^{4}$ Profs. Drs. do Dept ${ }^{\circ}$ de Tecnologia de Alimentos, Universidade Federal do Ceará, UFC, Fortaleza, CE. E-mail: evania@ufc.br; garraes@pq.cnpq.br; figueira@ufc.br

${ }^{5}$ Prof. Dr. do Instituto de Cultura e Arte, Universidade Federal do Ceará, UFC, Fortaleza, CE. E-mail: phenriquemachado@gmail.com

* Author for correspondence
} 


\section{Introduction}

Among cultivated fruit, the cashew tree stands out in the socioeconomic context due the high nutritional and commercial value of its products, the production and industrialization of which guarantee a significant income stream and generate thousands of jobs (PEREIRA et al., 2005).

From the cashew tree, the cashew is obtained which is composed of a cashew nut and a cashew apple. The cashew nut is composed of shell, film and nut itself. The nut is the edible fruit and has a high nutritional value.

In the last decade, the interest of scientists in organic cultivation has increased greatly, especially in comparison to conventional agriculture (LIMA et al., 2007). Ormond et al. (2002) affirm that organic products have no apparent differences when compared with conventional products. The differences observed in organic products derive from their nutritional benefits and absence of toxic contaminants. However, in the literature, there are only a few works that study whether there is any variation in the composition of organic foods when compared to conventional foods.

The preservation of the characteristics of food, for as long as possible after its transformation, is a major goal of the food industry.

Given the above, this research aimed to study the stability of cashew nuts obtained from conventional and organic cultivation.

\section{Material and Methods}

The study was performed with cashew nuts given by a large company in the Northeast of Brazil located in the city of Mossoró in the state of Rio Grande do Norte. The weather of the city of Mossoró is the semiarid, with mean temperatures of $27^{\circ} \mathrm{C}$.

The conventional and organic cashew trees studied were cultivated at the same farm (using the same environmental conditions) and belonged to the same specie (Anacardium occidentale) and variety (early dwarf cashew trees).

The samples were packed in flexible packaging covered with laminated film until analysis, and were crushed in a domestic blender just before the time of analysis. Samples were analyzed for water activity, total acidity, $\mathrm{pH}$, soluble solids, moisture, lipids, proteins and acidity of the lipid fraction according to the methods described by Adolfo Lutz Institute (IAL, 2008), total soluble sugar and reducing sugar (MILLER, 1959), ash (AOAC, 1996), total extractable polyphenols (TEP) (LARRAURI; RUPEREZ; SAURA-CALIXTO, 1997). The antioxidant activity was estimated by the methods with the radicals $\mathrm{ABTS}^{\cdot+}$ (RE et al., 1999) and DPPH• (BRAND-WILLIAMS; CUVELIER; BERSET, 1995). These analyses were performed at $0,30,60,90,120,150$ and 180 days of storage at room temperature $\left(25^{\circ} \mathrm{C}\right)$.

The water activity was determined by direct reading of the crushed samples, using the digital Higrotermo 95.

For the determination of the titratable acidity, 1 $\mathrm{g}$ of crushed cashew nut diluted in $50 \mathrm{~mL}$ of water was used. The titration was performed with $\mathrm{NaOH}$ $(0.1 \mathrm{~N})$ and phenolphthalein $1 \%$ as indicator.

The $\mathrm{pH}$ was measured directly in the crushed cashew nut diluted in water $(1 \mathrm{~g}$ cashew nut in 50 $\mathrm{mL}$ of water).

The total soluble solids were determined using $1 \mathrm{~g}$ of crushed cashew nut diluted in $50 \mathrm{~mL}$ and filtering through a filter paper. The read was performed in a digital refractometer (Atago N-1).

The moisture was determined by the direct heating in the oven $\left(121^{\circ} \mathrm{C}\right)$ of $5 \mathrm{~g}$ of crushed cashew nut until the constant weight was obtained.

The lipids were extracted in Soxhlet apparatus, using hexane as solvent.

The content of proteins was measured by microKjeldahl method. The protein-nitrogen conversion factor used to estimate the protein level was 6.25. 
For the determination of the acidity of the lipid fraction, $2 \mathrm{~g}$ of lipid was diluted in $25 \mathrm{~mL}$ of ether-ethanol solution $(2: 1)$. The titration of that solution was performed using $\mathrm{NaOH}(0.1 \mathrm{~N})$ and phenolphthalein $1 \%$ as indicator.

The total and reducing sugars were measured by the DNS (dinitrosalicylic acid) method, using $5 \mathrm{~g}$ of crushed cashew nut.

The ash was determined in a muffle furnace at $550^{\circ} \mathrm{C}$, using $2.5 \mathrm{~g}$ of crushed cashew nut.

The extracts for the determination of the TEP and the total antioxidant activity were prepared using defatted nuts. The process to remove the fat consisted of weight $10 \mathrm{~g}$ of crushed nuts and addition of 20 $\mathrm{mL}$ of hexane followed by agitation of the solution for 20 minutes in a magnetic stirrer and subsequent centrifugation at $3000 \mathrm{rpm}$ for 15 minutes. The supernatant was used to determine the acidity index of the lipid fraction and the residue was placed in the chapel chemistry to complete evaporation of hexane, according to the methodology proposed by Cavalcante (2010). The extract of defatted nuts was prepared according to Larrauri, Ruperez and SauraCalixto (1997) using ethanol (50\%) and acetone $(70 \%)$ and the centrifugations were performed at $3000 \mathrm{rpm}$.

In order to determine the antioxidant activity by $\mathrm{ABTS}^{\cdot+}$ and $\mathrm{DPPH}^{\cdot}$ assays, extracts in the following concentrations: 25000, 50000, 100000 and $200000 \mathrm{ppm}$ were used. The reading (Shimadzu spectrophotometer Model UV - 1800) of the samples by ABTS $^{\cdot+}$ assay was performed six minutes after the addition of alcoholic solution of $\mathrm{ABTS}^{\cdot+}$ at 734 $\mathrm{nm}$. In the DPPH${ }^{\bullet}$ assay, the reading was performed thirty minutes after mixing the cashew nut extract with ethanolic solution of $0.06 \mathrm{mM} \mathrm{DPPH}^{*}$ at 515 nm.
The microbiological analysis of coliforms at 35 ${ }^{\circ} \mathrm{C}$, coliforms at $45{ }^{\circ} \mathrm{C}$, Staphylococcus coagulase positive, yeast and mold, Enterobacteria, aerobic mesophilic and Salmonella sp were performed using methods described by APHA(2001).

The experiment was conducted in a randomized block design using two treatments (conventional and organic cultivation) in the parcels and seven storage times $(0,30,60,90,120,150$ and 180 days $)$ in the sub parcels with three replications.

In order to check the influence of the cultivation forms with the storage time, the results were subjected to analysis of interaction between these two variables. When was appropriate the regression analysis was performed and the models (linear, quadratic and cubic) were tested.

All the statistic tests were performed using the SAS statistical software version 8.1 (2006).

\section{Results and Discussion}

Chemical, physicochemical, total extractable polyphenols and antioxidant activity

There was significant interaction $(p<0.05)$ between the two forms of cultivation and the storage time for the following parameters: water activity, total acidity, $\mathrm{pH}$, soluble solids, total soluble sugars, ash, total extractable polyphenols and antioxidant activity by the test with $\mathrm{DPPH}^{\circ}$ free radical (Table 1), which indicated that there were significant difference $(p<0.05)$ between the two forms of cultivation, either between the storage time, or between both methods of cultivation and storage time together. 


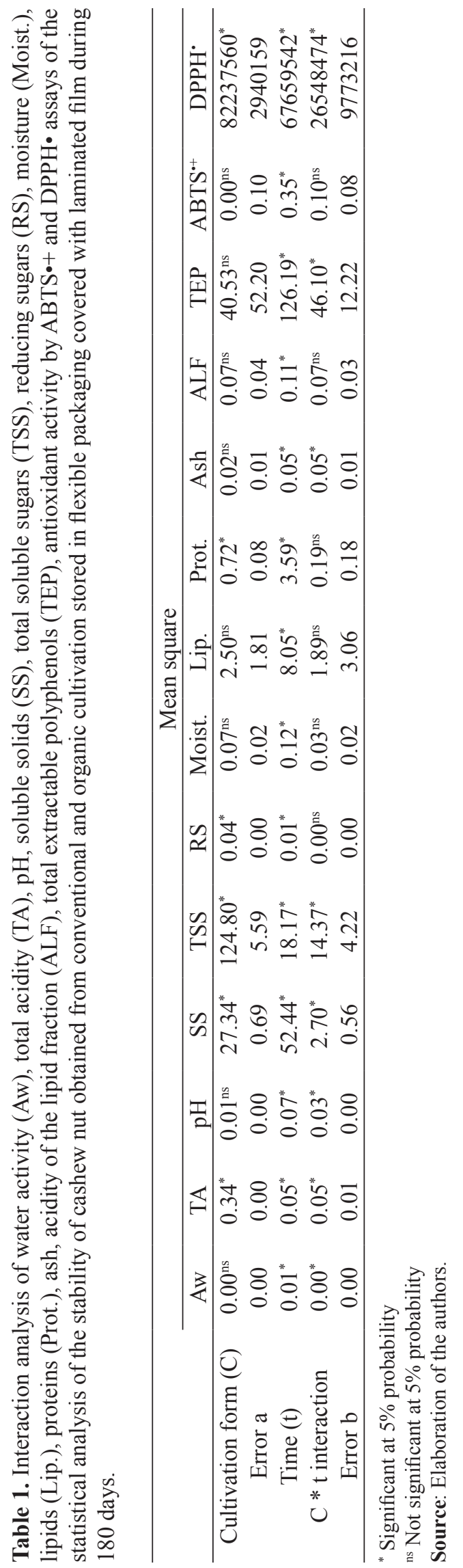

The models tested did not adjust to the data of water activity, total acidity, $\mathrm{pH}$, reducing sugars, lipids, proteins, ash and antioxidant activity by the tests with the radicals $\mathrm{ABTS}^{\circ+}$ and $\mathrm{DPPH}^{\bullet}$. The models which adjusted to the data of the other analyses are shown in Figures 1, 2, 3, 4 and 5.

The highest water activity during the storage was 0.62 in both forms of cultivation studied (Table 2). There was no influence of the cultivation forms with the storage time. There was little variation of water activity during the storage, presenting significant difference $(\mathrm{p}<0.05)$ during the storage time (Table 1). Lima and Borges (2004) who studied the effect of packaging on storage of cashew nut, observed that the use of flexible packaging covered with laminated film meant that the water activity (Aw) of nuts presented small oscillations and at the end of 250 days of storage the Aw values were similar to those observed in the initial period.

The nuts had a maximum acidity of $1.26 \mathrm{~g}$ oleic $\mathrm{acid} / 100 \mathrm{~g}$ in nuts from conventional cultivation, which was higher than the maximum found in nuts from organic cultivation (1.01 g oleic acid/100 g) (Table 2) presenting significant difference $(\mathrm{p}<0.05)$ between the two forms of cultivation (Table 1). Similar results were observed by Lima and Borges (2004) who observed that the levels of acidity showed little changes, with the value on the first day of storage of $0.54 \mathrm{~g}$ oleic acid/100 $\mathrm{g}$ and in 102 days of $1.31 \mathrm{~g}$ oleic acid/100 $\mathrm{g}$.

The results of $\mathrm{pH}$ in both forms of cultivation were similar to those observed by Cavalcante (2010), who reported $\mathrm{pH}$ values of 6.57 in cashew nuts. There was no significant difference $(p>0.05)$ between the two forms of cultivation studied. A slight increase during the storage time in both cultivation forms studied were observed (Table 3). 
Table 2. Mean \pm standard deviation of water activity and total acidity of cashew nuts obtained from conventional (Conv.) and organic (Org.) cultivation stored in flexible packaging covered with laminated film during 180 days.

\begin{tabular}{ccccc}
\hline \multirow{2}{*}{ Time (Days) } & \multicolumn{2}{c}{ Water activity } & \multicolumn{2}{c}{$\begin{array}{c}\text { Total acidity } \\
\text { (mg oleic acid/100 mL) }\end{array}$} \\
\cline { 2 - 5 } & Conv. & Org. & Conv. & Org. \\
\hline 0 & $0.56 \pm 0.01$ & $0.56 \pm 0.00$ & $0.84 \pm 0.07$ & $0.81 \pm 0.00$ \\
30 & $0.44 \pm 0.00$ & $0.48 \pm 0.00$ & $0.99 \pm 0.15$ & $0.95 \pm 0.12$ \\
60 & $0.55 \pm 0.01$ & $0.51 \pm 0.01$ & $1.26 \pm 0.16$ & $0.79 \pm 0.01$ \\
90 & $0.58 \pm 0.01$ & $0.58 \pm 0.00$ & $1.20 \pm 0.14$ & $0.82 \pm 0.01$ \\
120 & $0.58 \pm 0.02$ & $0.58 \pm 0.00$ & $1.10 \pm 0.01$ & $1.01 \pm 0.16$ \\
150 & $0.62 \pm 0.01$ & $0.62 \pm 0.00$ & $0.82 \pm 0.00$ & $0.83 \pm 0.00$ \\
180 & $0.56 \pm 0.04$ & $0.59 \pm 0.00$ & $1.10 \pm 0.02$ & $0.83 \pm 0.01$ \\
\hline
\end{tabular}

Source: Elaboration of the authors.

Table 3. Mean \pm standard deviation of $\mathrm{pH}$ and soluble solids of cashew nuts obtained from conventional (Conv.) and organic (Org.) cultivation stored in flexible packaging covered with laminated film during 180 days.

\begin{tabular}{cccrr}
\hline \multirow{2}{*}{ Time (Days) } & \multicolumn{2}{c}{$\mathrm{pH}$} & \multicolumn{2}{c}{$\begin{array}{c}\text { Soluble solids } \\
\left({ }^{\circ} \text { Brix }\right)\end{array}$} \\
\cline { 2 - 5 } & Conv. & Org. & \multicolumn{1}{c}{ Conv. } & Org. \\
\hline 0 & $6.20 \pm 0.07$ & $6.35 \pm 0.02$ & $8.32 \pm 0.71$ & $5.81 \pm 0.74$ \\
30 & $6.33 \pm 0.01$ & $6.50 \pm 0.01$ & $11.72 \pm 0.38$ & $9.70 \pm 0.54$ \\
60 & $6.57 \pm 0.12$ & $6.48 \pm 0.02$ & $14.71 \pm 0.57$ & $12.70 \pm 2.27$ \\
90 & $6.54 \pm 0.11$ & $6.55 \pm 0.05$ & $12.81 \pm 0.53$ & $13.98 \pm 0.42$ \\
120 & $6.36 \pm 0.01$ & $6.50 \pm 0.02$ & $15.47 \pm 1.04$ & $12.96 \pm 0.79$ \\
150 & $6.70 \pm 0.14$ & $6.49 \pm 0.01$ & $14.41 \pm 0.65$ & $12.08 \pm 1.01$ \\
180 & $6.51 \pm 0.07$ & $6.55 \pm 0.01$ & $8.73 \pm 0.56$ & $7.42 \pm 1.52$ \\
\hline
\end{tabular}

Source: Elaboration of the authors.

The quadratic model was adjusted to the data of nuts from organic cultivation and none of the models tested adjusted to the results of nuts from conventional cultivation for the content of soluble solids (Figure 1). The average observed for this parameter was higher in conventional than in organic nuts (Table 3).

The content of total soluble sugars in nuts from conventional cultivation increased linearly during the storage. The cubic model was adjusted in nuts from organic cultivation (Figure 2). There was significant difference $(p<0.05)$ between the two forms of cultivation and among the time of storage (Table 1).

As observed in the values of soluble solids, it can be seen that the values of total soluble sugars in the cashew nuts were higher in nuts from conventional than nuts from organic cultivation (Table 4), presenting difference $(p<0.05)$ between these two forms of cultivation (Table 1). The values observed in the present study are close to those reported by FAO (2010). 
Figure 1. Soluble solids of cashew nuts obtained from conventional and organic cultivation stored in flexible packaging covered with laminated film during 180 days.

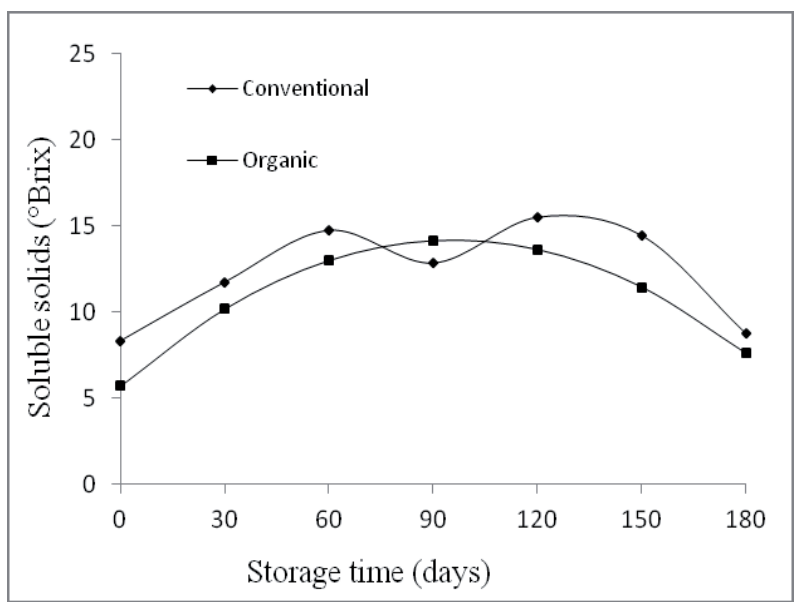

Source: Elaboration of the authors.

Figure 2. Total soluble sugar of cashew nuts obtained from conventional and organic cultivation stored in flexible packaging covered with laminated film during 180 days.

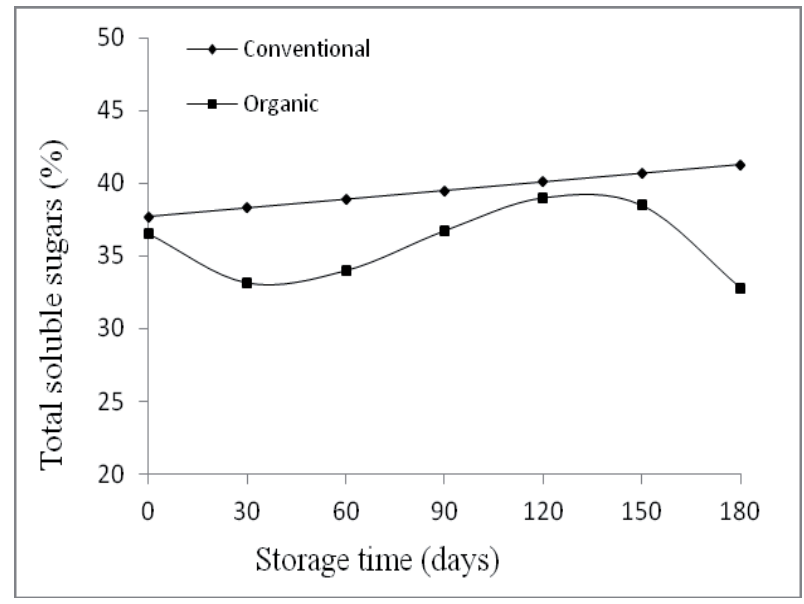

Source: Elaboration of the authors.

Table 4. Mean \pm standard deviation of total soluble sugar and reducing sugar of cashew nuts obtained from conventional (Conv.) and organic (Org.) cultivation stored in flexible packaging covered with laminated film during 180 days.

\begin{tabular}{ccccc}
\hline \multirow{2}{*}{ Time (Days) } & \multicolumn{2}{c}{ Total Soluble Sugar (\%) } & \multicolumn{2}{c}{ Reducing Sugar (\%) } \\
\cline { 2 - 5 } & Conv. & Org. & Conv. & Org. \\
\hline 0 & $35.44 \pm 1.05$ & $36.49 \pm 0.15$ & $0.32 \pm 0.08$ & $0.32 \pm 0.02$ \\
30 & $38.94 \pm 3.74$ & $33.29 \pm 0.55$ & $0.26 \pm 0.00$ & $0.22 \pm 0.04$ \\
60 & $41.98 \pm 1.99$ & $35.24 \pm 4.18$ & $0.14 \pm 0.02$ & $0.13 \pm 0.01$ \\
90 & $38.27 \pm 2.67$ & $37.23 \pm 2.49$ & $0.15 \pm 0.01$ & $0.16 \pm 0.02$ \\
120 & $40.38 \pm 2.11$ & $38.30 \pm 0.54$ & $0.19 \pm 0.06$ & $0.13 \pm 0.01$ \\
150 & $41.60 \pm 1.14$ & $39.11 \pm 1.99$ & $0.14 \pm 0.04$ & $0.14 \pm 0.02$ \\
180 & $39.79 \pm 0.50$ & $32.67 \pm 1.29$ & $0.17 \pm 0.01$ & $0.12 \pm 0.01$ \\
\hline
\end{tabular}

Source: Elaboration of the authors. 
The results of reducing sugars ranged from 0.14 to $0.32 \%$ in conventional nuts and from 0.13 to $0.32 \%$ in organic nuts (Table 4 ). There was significant difference $(\mathrm{p}<0.05)$ between the two forms of cultivation and among the time of storage, but there was no significance interaction $(p>0.05)$ between the variables, which means that the changes of reducing sugars in both cultivation forms were not influenced by the storage time.

Cashew nuts from different regions of India showed higher reducing sugars content, ranging from 1 to $3 \%$ (FAO, 2010). This difference may be due to the differences in maturity, climate and crop management.

The cubic model was adjusted to the moisture data (Figure 3). As there was no significant difference $(p>0.05)$ between the two forms of cultivation studied (Table 1), the overall average data is shown in Figure 3. There was little variation in the percentage of moisture of the nuts, but the highest values were observed at the end of storage. There was significant difference $(\mathrm{p}<0.05)$ between the time of storage (Table 1). Smaller percentages of moisture in cashew nuts are ideal for better conservation of nuts and acceptance by consumers. Low moisture contents can inhibit the growth of microorganisms and cause minimal changes in texture. According to Cavalcante (2010), the very moist nut becomes elastic and is little appreciated by consumers.

The maximum percentage of lipids was $41.72 \%$ and $42.73 \%$ in nuts from conventional and organic cultivation, respectively (Table 5), with no significant difference $(p>0.05)$ between the two cultivation forms (Table 1). These values are lower than those determined in cashew nuts by other authors: FAO (2010) (46\%), Cavalcante (2010) (44.14\%), Kornsteiner, Wagner and Elmadfa (2006) (47.1\%), Lima, García and Lima (2004) (46.64\%) and USDA (2010) (43.85\%).

Maximum values of $16.93 \%$ and $16.82 \%$ of protein in conventional and organic nuts, respectively, were observed (Table 6). Lima and Sousa (2001) observed percentages of protein ranging from 19.1 to $23.6 \%$ at the beginning of storage and 19.8 to $22.1 \%$ at the end of four months storage. Lima, Saraiva and Sousa (2009) found values close to this study (17\%) in cashew nuts. According to Freitas and Naves (2010), the difference in the contents of proteins in cashew nuts observed in the literature may be due to the proteinnitrogen conversion factor used to quantify the protein concentration.

Figure 3. Moisture of cashew nuts obtained from conventional and organic cultivation stored in flexible packaging covered with laminated film during 180 days.

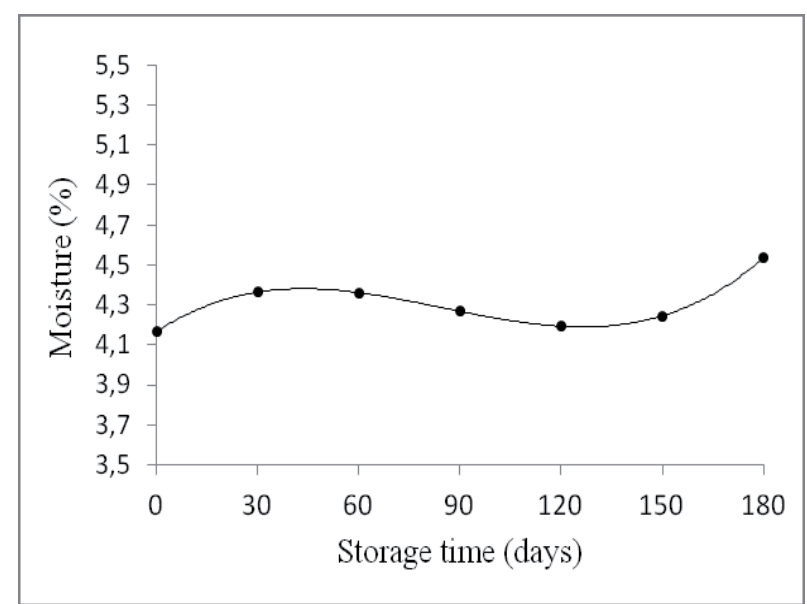

Source: Elaboration of the authors. 
Table 5. Mean \pm standard deviation of moisture and lipids of cashew nuts obtained from conventional (Conv.) and organic (Org.) Cultivation stored in flexible packaging covered with laminated film during 180 days.

\begin{tabular}{ccccc}
\hline \multirow{2}{*}{ Time (days) } & \multicolumn{2}{c}{ Moisture (\%) } & \multicolumn{2}{c}{ Lipids (\%) } \\
\cline { 2 - 5 } & Conv. & Org. & Conv. & Org. \\
\hline 0 & $4.22 \pm 0.05$ & $4.19 \pm 0.03$ & $40.30 \pm 2.15$ & $40.70 \pm 1.06$ \\
30 & $4.14 \pm 0.10$ & $4.39 \pm 0.09$ & $39.59 \pm 3.90$ & $41.50 \pm 1.35$ \\
60 & $4.43 \pm 0.05$ & $4.35 \pm 0.06$ & $39.75 \pm 0.90$ & $38.15 \pm 1.04$ \\
90 & $4.23 \pm 0.29$ & $4.44 \pm 0.29$ & $41.66 \pm 1.44$ & $42.86 \pm 1.41$ \\
120 & $4.12 \pm 0.13$ & $4.30 \pm 0.03$ & $41.72 \pm 2.52$ & $42.73 \pm 1.31$ \\
150 & $4.12 \pm 0.06$ & $4.19 \pm 0.19$ & $40.44 \pm 0.57$ & $40.36 \pm 0.24$ \\
180 & $4.58 \pm 0.06$ & $4.57 \pm 0.09$ & $40.91 \pm 1.27$ & $41.47 \pm 1.30$ \\
\hline
\end{tabular}

Source: Elaboration of the authors.

Table 6. Mean \pm standard deviation of proteins and ash of cashew nuts obtained from conventional (Conv.) and organic (Org.) cultivation stored in flexible packaging covered with laminated film during 180 days.

\begin{tabular}{ccccc}
\hline \multirow{2}{*}{ Time (days) } & \multicolumn{2}{c}{ Proteins (\%) } & \multicolumn{2}{c}{ Ash (\%) } \\
\cline { 2 - 5 } & \multicolumn{1}{c}{ Conv. } & Org. & Conv. & Org. \\
\hline 0 & $14.72 \pm 0.50$ & $14.83 \pm 0.63$ & $2.39 \pm 0.15$ & $2.57 \pm 0.11$ \\
30 & $14.76 \pm 0.49$ & $14.80 \pm 0.28$ & $2.30 \pm 0.01$ & $2.45 \pm 0.06$ \\
60 & $15.95 \pm 0.45$ & $15.74 \pm 0.44$ & $2.22 \pm 0.04$ & $2.56 \pm 0.18$ \\
90 & $16.93 \pm 0.17$ & $16.83 \pm 0.37$ & $2.59 \pm 0.08$ & $2.61 \pm 0.07$ \\
120 & $16.07 \pm 0.33$ & $15.13 \pm 0.59$ & $2.51 \pm 0.12$ & $2.45 \pm 0.07$ \\
150 & $14.89 \pm 0.27$ & $14.67 \pm 0.47$ & $2.71 \pm 0.15$ & $2.48 \pm 0.08$ \\
180 & $15.70 \pm 0.32$ & $15.20 \pm 0.02$ & $2.50 \pm 0.09$ & $2.41 \pm 0.12$ \\
\hline
\end{tabular}

Source: Elaboration of the authors.

The ash values observed in this study are consistent with those found by Cavalcante (2010), Lima, García and Lima (2004) and FAO (2010), which reported values of ash in cashew nut of $2.48 \%, 2.50 \%$ and $2.4 \%$, respectively. There was no significant difference $(p>0.05)$ between these two cultivation forms (Table 1).

The linear model was adjusted to the data of acidity of the lipid fraction (Figure 4). There was no significant difference $(p>0.05)$ between the two forms of cultivation studied (Table 1), so the overall average data is shown in Figure 4. The maximum values observed in this study were $1.48 \%$ of oleic acid in conventional nuts and $1.44 \%$ oleic acid in organic nuts (Table 7). Lima and Borges (2004) observed maximum values of acidity of the lipid fraction in cashew nuts of $1.50 \%$ and concluded that this value can be considered low, which indicates that nuts suffered hardly any hydrolytic rancidity processes during the storage.

The cubic model adjusted to the results of TEP in conventional nuts and none of the tested models adjusted to the results of organic nuts (Figure 5). There was no significant difference $(p>0.05)$ between the two forms of cultivation (Table 1). 
Figure 4. Acidity of the lipid fraction of cashew nuts obtained from conventional and organic cultivation stored in flexible packaging covered with laminated film during 180 days.

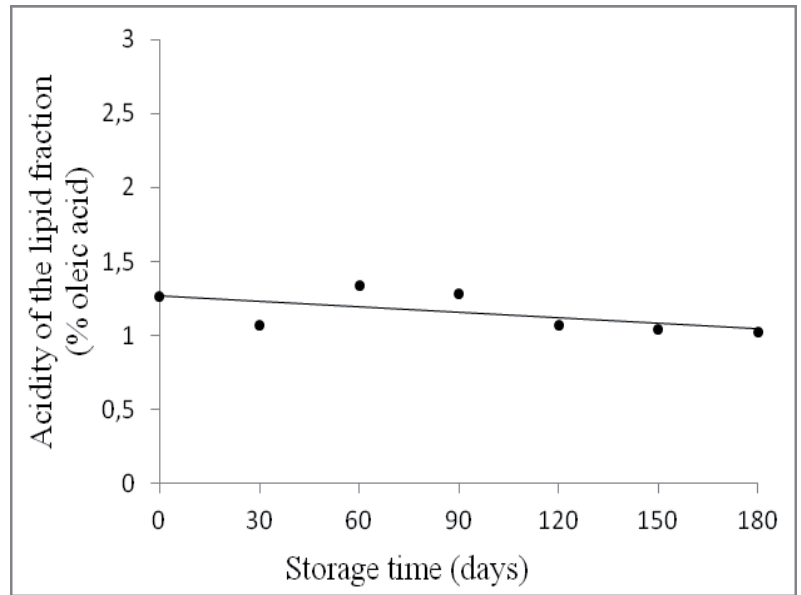

Source: Elaboration of the authors.

Table 7. Mean \pm standard deviation of acidity of the lipid fraction and total extractable polyphenols of cashew nuts obtained from conventional (Conv.) and organic (Org.) cultivation stored in flexible packaging covered with laminated film during 180 days.

\begin{tabular}{ccccc}
\hline \multirow{2}{*}{ Time (days) } & \multicolumn{2}{c}{ Acidity of the lipid fraction (\% oleic acid) } & \multicolumn{2}{c}{ Total Extractable Polyphenols (mg GAE/100 g) } \\
\cline { 2 - 5 } & Conv. & Org. & Conv. & Org. \\
\hline 0 & $1.44 \pm 0.32$ & $1.08 \pm 0.01$ & $63.46 \pm 2.69$ & $62.03 \pm 3.82$ \\
30 & $1.06 \pm 0.02$ & $1.07 \pm 0.01$ & $66.72 \pm 1.53$ & $62.77 \pm 3.03$ \\
60 & $1.24 \pm 0.31$ & $1.44 \pm 0.31$ & $65.83 \pm 3.31$ & $68.83 \pm 1.02$ \\
90 & $1.48 \pm 0.33$ & $1.09 \pm 0.00$ & $65.02 \pm 1.32$ & $66.32 \pm 1.70$ \\
120 & $1.08 \pm 0.01$ & $1.05 \pm 0.01$ & $60.17 \pm 2.31$ & $59.75 \pm 2.78$ \\
150 & $1.04 \pm 0.06$ & $1.04 \pm 0.05$ & $67.43 \pm 6.21$ & $53.84 \pm 6.60$ \\
180 & $1.03 \pm 0.07$ & $1.01 \pm 0.05$ & $73.35 \pm 5.01$ & $73.42 \pm 7.94$ \\
\hline
\end{tabular}

Source: Elaboration of the authors.

Figure 5. Total extractable polyphenols of cashew nuts obtained from conventional and organic cultivation stored in flexible packaging covered with laminated film during 180 days.

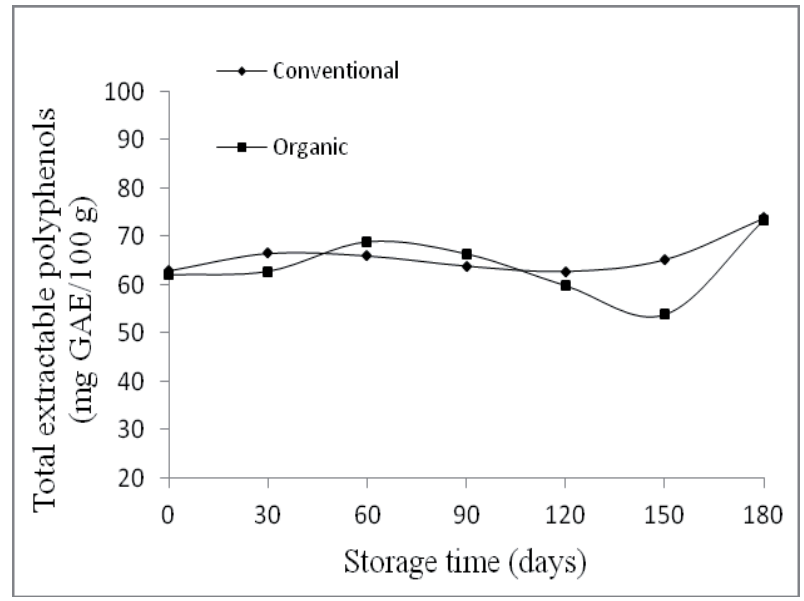

Source: Elaboration of the authors. 
The content of TEP ranged from 60.17 to 73.35 $\mathrm{mg}$ gallic acid equivalent (GAE)/100 $\mathrm{g}$ in nuts from conventional cultivation and 53.84 to $73.42 \mathrm{mg}$ GAE/100 $\mathrm{g}$ in nuts from organic cultivation (Table 7). Cavalcante (2010) found TEP content of 51.33 mg GAE/100 g, which was lower than the results obtained in this study.

Higher values were observed by Yang, Liu and Halim (2009) and Kornsteiner, Wagner and Elmadfa (2006), which were $86.7 \mathrm{mg}$ GAE/100 g and $137 \mathrm{mg}$ GAE/100 g, respectively. These authors used the mixture of acetone-hexane as reagent in the extraction of TEP. The differences in the levels of TEP can be explained by the extraction method and the solvents employed. Naczk and Shahidi
(2006) reported that the extraction of polyphenols from plant materials is influenced by the solubility of the solvent used for the extraction process. The variation in the content of phenolic compounds can also occur due to variety, climate and method of extraction (VASCO; RUALES; KAMAL-ELDIN, 2008).

The highest values for total antioxidant capacity by $\mathrm{ABTS}^{\cdot+}$ assay was $6.86 \mu \mathrm{M}$ Trolox/g in conventional nut and $6.96 \mu \mathrm{M}$ Trolox/g in organic nut (Table 8$)$. There was no significant difference ( $p>0.05$ ) between the two forms of cultivation (Table 1). A similar result was reported by Cavalcante (2010), who observed values of $6.49 \mu \mathrm{M}$ Trolox/g in cashew nut.

Table 8. Mean \pm standard deviation of the antioxidant activity by the methods with the $\mathrm{ABTS}^{*+}$ and $\mathrm{DPPH}^{*}$ radicals of cashew nuts obtained from conventional (Conv.) and organic (Org.) cultivation stored in flexible packaging covered with laminated film during 180 days.

\begin{tabular}{|c|c|c|c|c|}
\hline \multirow[t]{2}{*}{ Time (days) } & \multicolumn{2}{|c|}{$\begin{array}{c}\text { ABTS }^{++} \\
(\mu \mathrm{M} \text { Trolox } / g)\end{array}$} & \multicolumn{2}{|c|}{$\begin{array}{c}\mathrm{DPPH}^{\cdot} \\
(\mathrm{g} \text { nut } / \mathrm{g} \text { DPPH}) \\
\end{array}$} \\
\hline & Conv. & Org. & Conv. & Org. \\
\hline 0 & $6.70 \pm 0.24$ & $6.83 \pm 0.13$ & $27231 \pm 455$ & $29534 \pm 597$ \\
\hline 30 & $6.78 \pm 0.13$ & $6.83 \pm 0.11$ & $36046 \pm 2646$ & $33520 \pm 3210$ \\
\hline 60 & $6.67 \pm 0.12$ & $6.96 \pm 0.52$ & $26405 \pm 3836$ & $25247 \pm 2658$ \\
\hline 90 & $6.32 \pm 0.27$ & $6.51 \pm 0.29$ & $29447 \pm 6577$ & $31859 \pm 1803$ \\
\hline 120 & $6.38 \pm 0.23$ & $5.99 \pm 0.13$ & $26053 \pm 2090$ & $33767 \pm 3510$ \\
\hline 150 & $6.86 \pm 0.22$ & $6.53 \pm 0.10$ & $30702 \pm 3548$ & $39495 \pm 859$ \\
\hline 180 & $6.48 \pm 0.27$ & $6.43 \pm 0.64$ & $29413 \pm 468$ & $30826 \pm 2270$ \\
\hline
\end{tabular}

Source: Elaboration of the authors.

The results for total antioxidant activity by $\mathrm{DPPH}^{*}$ assay showed minimum value of $26405 \mathrm{~g}$ nut $/ \mathrm{g}$ of $\mathrm{DPPH}^{*}$ in conventional nut and $25247 \mathrm{~g} \mathrm{nut} / \mathrm{g}$ of $\mathrm{DPPH}^{\bullet}$ in organic nut (Table 8 ). These values are very high, indicating a low antioxidant capacity, since in the DPPH${ }^{*}$ assay the results are expressed according to the quantity of nut required to reduce $50 \%$ of the initial concentration of $\mathrm{DPPH}^{*}$ radical. The results obtained in this study were similar to that observed by Cavalcante (2010), who obtained a value of $29964 \mathrm{~g}$ nut $/ \mathrm{g}$ of $\mathrm{DPPH}^{*}$ in cashew nut.
There was no reduction in the antioxidant activity of the cashew nut during the storage. This can be explained by the use of flexible packaging covered with laminated film throughout storage, which provided protection against the incidence of light on the nuts.

\section{Microbiological Analysis}

The Brazilian Legislation sets the standards for microbiological walnuts, almonds, peanuts and similar, raw, whole or peeled, tolerating a 
maximum of $10^{3} \mathrm{CFU} / \mathrm{g}$ for coliforms at $45^{\circ} \mathrm{C}$ and absence of Salmonella sp./25 $\mathrm{g}$ for indicative sample (BRASIL, 2001). Nuts from conventional and organic cultivation stored in flexible packaging covered with laminated film attained the standard of Brazilian Legislation and are suitable for consumption during 180 days of storage (Table 9).
During processing, cashew nuts are manipulated quite a lot in the steps of selection and classification, but the presence of Staphylococcus coagulase positive was not detected (Table 9). This result can be associated with the acid present in these nuts that is effective against Gram positive bacteria, as well as the good hygiene of food handlers.

Table 9. Microbiological data of of cashew nuts obtained from conventional (Conv.) and organic (Org.) cultivation stored in flexible packaging covered with laminated film during 180 days.

\begin{tabular}{|c|c|c|c|c|c|c|c|c|}
\hline $\begin{array}{l}\text { Time } \\
\text { (days) }\end{array}$ & $\begin{array}{l}\text { Cultivation } \\
\text { form }\end{array}$ & $\begin{array}{l}\text { Coliforms } \\
\text { at } 35^{\circ} \mathrm{C}^{*}\end{array}$ & $\begin{array}{l}\text { Coliforms } \\
\text { at } 45^{\circ} \mathrm{C}^{*}\end{array}$ & $\begin{array}{c}\text { Staphylococcus } \\
\text { coagulase } \\
\text { positive* }\end{array}$ & $\begin{array}{l}\text { Yeast/ } \\
\text { mold* }\end{array}$ & Enterobacteria* & $\begin{array}{c}\text { Aerobic } \\
\text { Mesophilic }^{*}\end{array}$ & $\begin{array}{l}\text { Salmonella } \\
\text { sp. }{ }^{* *}\end{array}$ \\
\hline \multirow{2}{*}{0} & Conv. & $<10$ & $<10$ & $<10$ & $1.0 \times 10$ & $<10$ & $5.0 \times 10$ & Absence \\
\hline & Org. & $5.4 \times 10^{2}$ & $<10$ & $<10$ & $1.0 \times 10$ & $5.0 \times 10^{2}$ & $7.3 \times 10^{2}$ & Absence \\
\hline \multirow{2}{*}{30} & Conv. & $<10$ & $<10$ & $<10$ & $5.0 \times 10$ & $<10$ & $8.0 \times 10$ & Absence \\
\hline & Org. & $<10$ & $<10$ & $<10$ & $1.0 \times 10$ & $<10$ & $<10$ & Absence \\
\hline \multirow{2}{*}{60} & Conv. & $<10$ & $<10$ & $<10$ & $1.0 \times 10$ & $<10$ & $2.0 \times 10$ & Absence \\
\hline & Org. & $<10$ & $<10$ & $<10$ & $<10$ & $<10$ & $<10$ & Absence \\
\hline \multirow{2}{*}{90} & Conv. & $<10$ & $<10$ & $<10$ & $5.0 \times 10$ & $<10$ & $1.0 \times 10$ & Absence \\
\hline & Org. & $<10$ & $<10$ & $<10$ & $2.0 \times 10$ & $<10$ & $1.0 \times 10$ & Absence \\
\hline \multirow{2}{*}{120} & Conv. & $<10$ & $<10$ & $<10$ & $1.0 \times 10$ & $<10$ & $1.0 \times 10$ & Absence \\
\hline & Org. & $<10$ & $<10$ & $<10$ & $<10$ & $<10$ & $2.0 \times 10$ & Absence \\
\hline \multirow{2}{*}{150} & Conv. & $<10$ & $<10$ & $<10$ & $2.0 \times 10$ & $<10$ & $1.0 \times 10$ & Absence \\
\hline & Org. & $<10$ & $<10$ & $<10$ & $<10$ & $<10$ & $1.0 \times 10$ & Absence \\
\hline \multirow{2}{*}{180} & Conv. & $<10$ & $<10$ & $<10$ & $2.0 \times 10$ & $<10$ & $4.0 \times 10$ & Absence \\
\hline & Org. & $<10$ & $<10$ & $<10$ & $1.0 \times 10$ & $<10$ & $1.0 \times 10$ & Absence \\
\hline
\end{tabular}

* CFU: colony forming units/g.

** Absence in $25 \mathrm{~g}$ of nut.

Source: Elaboration of the authors.

The low water activity of conventional ( 0.44 to $0.62)$ and organic nuts (0.48 to 0.62$)$ (Table 2) are limiting factors for growth of bacteria and mold mycotoxin producers. However cashew nuts, when contaminated, can be vehicles of bacteria.

In Table 5 it can be observed that there was a low contamination of cashew nuts with coliforms at $35{ }^{\circ} \mathrm{C}$, mesophilic bacteria, Enterobacteria, yeasts and molds, indicating good manufacturing practices during the processing.

At 0 days of storage, in both cultivation forms studied, the aerobic mesophilic count was higher than in the others storage time studied, which may occurred due to the failure in the sealing step (which may have favored the growth of this type of microorganism) or due to contamination with these microorganisms while collecting the samples.

Similar results were observed by Lima and Bruno (2007) who studied the stability of the cashew nut for 300 days. These authors observed counts of coliforms at $45{ }^{\circ} \mathrm{C}<10 \mathrm{MPN} / \mathrm{g}$, absence of Salmonella spp./25 $\mathrm{g}$ and yeast and mold counts ranging from $<100$ to $10^{3} \mathrm{CFU} / \mathrm{g}$.

Costa et al. (2009), studying the stability of the raw cashew nut and the toasted and salted cashew nut for 360 days, observed that both presented 
absence of Salmonella spp./25 g, low counts of coliforms at $35{ }^{\circ} \mathrm{C}(<10 \mathrm{MPN} / \mathrm{g})$ and coliforms at $45{ }^{\circ} \mathrm{C}(<10 \mathrm{MPN} / \mathrm{g})$ during the storage time.

\section{Conclusions}

Cashew nuts from conventional and organic cultivation presented similar values of reducing sugar, moisture, lipids, acidity of the lipid fraction, protein and antioxidant activity by $\mathrm{ABTS}^{\cdot+}$ assay.

The highest values of total soluble sugars and soluble solids were observed in nuts from conventional cultivation.

The cashew nut presented good levels of bioactive compounds, and a good source of natural antioxidants. There was no reduction of the antioxidant activity of the cashew nuts during the storage in flexible packaging covered with laminated film, at room temperature $\left(25^{\circ} \mathrm{C}\right)$ during 180 days.

The nuts from conventional and organic cultivation, during the storage in flexible packaging covered with laminated film for 180 days, showed acidity and $\mathrm{pH}$ values conducive to the growth of microorganisms. However, the low values of water activity and moisture favored the microbiological stability of this product and it fell within the limits recommended by Brazilian Legislation.

\section{References}

ASSOCIATION OF OFFICIAL ANALYTICAL CHEMISTS - AOAC. Official methods of analysis of the association of official analytical chemists (method 900.02). 16. ed. Gaithersburg, Maryland: AOAC International, 1996. Chapter 44. p. 3.

AMERICAN PUBLIC HEALTH ASSOCIATION - APHA. Downes \& Ito (Coord.). Compendium of methods for the microbiological examination of foods. Washington, DC: American Public Health Association, 2001. p. 676.
BRAND-WILLIANS, W.; CUVELIER, M. E.; BERSET, C. Use of free radical method evaluate antioxidant activity. Food Science and Technology, London, v. 28, n. 1, p. 25-30, 1995.

BRASIL. Agência Nacional de Vigilância Sanitária. Resolução RDC n. 12, de 02 de janeiro de 2001. Regulamento técnico sobre os padrões microbiológicos para alimentos. Diário Oficial [da] União, Brasília, 02 jan. 2001, p. 1-54. Available at: <http://www.anvisa.gov. br/legis/resol/12_01rdc.htm>. Accessed at: 26 jun. 2012.

CAVAlCANTE, C. E. B. Atividade antioxidante total durante o processamento de amêndoas de castanha de caju (Anacardium ocidentale L.). 2010. Dissertação (Mestrado em Ciência e Tecnologia de Alimentos) Departamento de Tecnologia de Alimentos. Universidade Federal do Ceará, Fortaleza.

COSTA, J. M. C.; GUERRA, K. T.; MAIA, G. A.; ROCHA, E. M. F. F. Avaliação físico-química e microbiológica da amêndoa da castanha de caju. Ciências Exatas e da Terra, Ciências Agrárias e Engenharias, Ponta Grossa, v. 15, n. 3, p. 181-187, 2009.

FOOD AND AGRICULTURE ORGANIZATION OF THE UNITED NATIONS - FAO. Integrated production practices of cashew in Asia. 2010. Available at: <http:// www.fao.org/docrep/005/ac451e/ac451e0b.htm>. Accessed at: 15 apr. 2010.

FREITAS, J. B.; NAVES, M. M. V. Composição química de nozes e sementes comestíveis e sua relação com a nutrição e saúde. Revista de Nutrição, Campinas, v. 23, n. 2, p. 269-279, 2010.

INSTITUTO ADOLFO LUTZ - IAL. Métodos físicoquímicos para análise de alimentos. 6. ed. São Paulo: Instituto Adolfo Lutz, 2008. 1020 p.

KORNSTEINER, M.; WAGNER, K. H.; ELMADFA, I. Tocopherols and total phenolics in 10 different nut types. Food Chemistry, Oxford, v. 98, n. 2, p. 381-387, 2006.

LARRAURI, J. A.; RUPEREZ, P.; SAURA-CALIXTO, F. Effect of drying temperature on the stabilitity of polyphenols and antioxidant activity of red grape pomace peels. Journal of Agricultural and Food Chemistry, Washington, v. 45, n. 4, p. 1390-1393, 1997.

LIMA, A. C.; GARCÍA, N. H. P.; LIMA, J. R. Obtenção e caracterização dos principais produtos do caju. Boletim do Centro de Pesquisa e Processamento de Alimentos, Curitiba, v. 22, p. 134-144. 2004. 
LIMA, H. V.; OLIVEIRA, T. S.; OLIVEIRA, M. M.; MENDONÇA E. S.; LIMA, P. J. B. F. Indicadores de qualidade do solo em sistemas de cultivo orgânico e convencional no semi-árido cearense. Revista Brasileira de Ciência do Solo, Viçosa, v. 31, n. 5, p. 1085-1098, 2007.

LIMA, J. R.; BORGES, M. F. Armazenamento de amêndoas de castanha de caju: influência da embalagem e da salga. Revista Ciência Agronômica, Fortaleza, v. 35, n. 1, p. 104-109, 2004.

LIMA, J. R.; BRUNO, L. M. Estabilidade de pasta de amêndoa de castanha de caju. Revista Ciência e Tecnologia de Alimentos, Campinas, v. 27, n. 4, p. 816822. 2007.

LIMA, J. R.; SARAIVA, S. C. O.; SOUSA, A. V. Preparação e características de pastas de amêndoas de castanha de caju e amendoim. Fortaleza: Embrapa Agroindústria Tropical, 2009. 2 p. (Comunicado técnico, 144).

LIMA, J. R.; SOUSA, M. M. M. Influência do tipo de óleo utilizado para fritura na estabilidade de amêndoas de castanha de caju. Boletim do Centro de Pesquisa e Processamento de Alimentos, Curitiba, v. 19, n. 1, p. 4352. 2001.

MILLER, G. L. Use of dinitrosalicilic acid reagent for determination of reducing sugar. Analytical Biochemistry, New York, v. 31, n. 3, p. 426-428, 1959.

NACZK, M.; SHAHIDI, F. Phenolics in cereals, fruits and vegetables: occurrence, extraction and analysis. Journal of Pharmaceutical and Biomedical Analysis, Georgia, v. 41, n. 5, p. 1523-1542. 2006.
ORMOND, J. G. P.; PAULA, S. R. L.; FAVERET FILHO, P.; ROCHA, L. T. M. Agricultura orgânica: quando o passado é futuro. Rio de Janeiro: BNDES Setorial, 2002. p. 3-34.

PEREIRA, M. C. T.; CORREA, H. C. T.; NIETSCHE, S.; MOTA, W. F.; MARQUES, S. V. Caracterização físicoquímica de pedúnculos e castanhas de clones de cajueiroanão precoce nas condições do norte de Minas Gerais. Bragantia, São Paulo, v. 64, n. 2, p. 169-175. 2005.

RE, R.; PELLEGRINI, A. P.; PANNALA, A.; YANG, M.; RICE-EVANS, C. Antioxidant activity applying an improved ABTS radical cation decolorization assay. Free Radical Biology \& Medicine, New York, v. 26, n. 9-10, p. 1231-1237, 1999.

STATISTICAL ANALYSIS SYSTEM INSTITUTE - SAS. SAS user's guide: version 9.1, Cary, NC: SAS Institute, Inc. 2006.

UNITED STATES DEPARTMENT OF AGRICULTURE - USDA. National nutrient database for standard reference. 2009. Available at: <http://www.nal.usda.gov/ fnic/foodcomp/search/>. Accessed at: 22 sept. 2010.

VASCO, C.; RUALES, J.; KAMAL-ELDIN, A. Total phenolic compounds and antioxidant capacities of major fruits from Ecuador. Food Chemistry, Oxford, v. 111, n. 4, p. 816-823, 2008.

YANG, J.; LIU, R. H.; HALIM, H. Antioxidant and antiproliferative activities of common edible nut seeds. Food Science and Technology, London, v. 42, n. 1, p. 1-8, 2009. 
